\title{
Social representations of Mexican pregnant teenagers about the puerperal care, lactation, and newborn care
}

\author{
Julieta A. Franco-Ramírez, Carlos E. Cabrera-Pivaral, Gabriel Zárate-Guerrero, Sergio A. Franco-Chávez, \\ María Á. Covarrubias-Bermúdez*, and Marco A. Zavala-González \\ Centro Universitario de Ciencias de la Salud, Universidad de Guadalajara, Guadalajara, Jalisco, Mexico
}

\begin{abstract}
Background: Puerperal care and feeding of the newborn are guided by entrenched cultural meanings between women, so it is important to know and identify how they are acquired and perpetuated. Regarding this knowledge, the social representations that Mexican pregnant teenagers have about puerperium, lactation, and newborn care were studied. Methods: An interpretative study was made based on the principles of the theory of social representations. Interviews were conducted to obtain information from 30 Mexican adolescents who attended prenatal care at the gynecological obstetrics area in a second-level hospital during 2015. Classical content analysis strategies were applied to analyze the information; this process consisted of coding and categorizing information. A conceptual map was also developed to describe the social representations found. Results: In this study, 190 codes and three social representations were identified: "breastfeeding is a practice based on myths,"'newborns are fragile," and "mother and child must be synchronized." Conclusions: Three social representations that explain the practices of adolescents toward breastfeeding and the care of them and their children were identified. They were acquired through family communication and strengthened by the need for support due to the temporary or permanent absence of the couple, personal crises motivated by bodily changes, fear of new modifications due to breastfeeding and ignorance about how to carry out breastfeeding and care during the puerperium.
\end{abstract}

Key words: Postnatal care. Breastfeeding. Pregnancy in adolescence. Qualitative research. Mexico.

\section{Representaciones sociales de adolescentes mexicanas embarazadas sobre el puerperio, lactancia y cuidados del recién nacido}

\section{Resumen}

Introducción: Los cuidados durante el puerperio y la alimentación del recién nacido están guiados por significados culturales afianzados entre las mujeres, por lo que es importante conocerlos e identificar cómo se adquieren y perpetúan. En este tenor, se estudiaron las representaciones sociales que tienen adolescentes mexicanas embarazadas sobre el puerperio, la lactancia y el cuidado del recién nacido. Métodos: Se realizó un estudio interpretativo basado en los principios de la teoría de las representaciones sociales. Se realizaron entrevistas para obtener información de 30 adolescentes mexicanas

Date of reception: 24-07-2017

*María de los Ángeles Covarrubias-Bermúdez

E-mail: angelescovarrubias@ hotmail.com

2444-3409/O 2018. Hospitat Infantil de México Federico
Date of acceptance: 03-12-2017

DOI: 10.24875/BMHIME.M18000034
Available online: 14-11-2018

Bol Med Hosp Infant Mex. 2018;75:130-137

www.bmhim.com 
que asistieron a control prenatal al área de ginecoobstetricia en un hospital de segundo nivel de atención durante 2015. Se aplicaron estrategias de análisis de contenido clásico para analizar la información; este proceso consistió en codificar y categorizar la información. También se elaboró un mapa conceptual para describir las representaciones sociales encontradas. Resultados: Se identificaron 190 códigos y tres representaciones sociales: "lactancia: práctica mitificada», "los recién nacidos son frágiles» $y$ "madre e hijo deben sincronizarse». Conclusiones: Se identificaron tres representaciones sociales que explicaron las prácticas de las adolescentes hacia la lactancia y el cuidado de ellas y sus hijos, adquiridas mediante la comunicación familiar y afianzadas por la necesidad de apoyo debido a ausencia temporal o permanente de pareja, crisis personales motivadas por los cambios corporales, miedo a sufrir cambios por la lactancia y desconocimiento sobre cómo llevar a cabo la lactancia y los cuidados durante el puerperio.

Palabras clave: Atención posnatal. Lactancia materna. Embarazo en adolescencia. Investigación cualitativa. México.

\section{Introduction}

The care of the postpartum women and the neonate is associated with a decrease in maternal and infant deaths, whose frequency was 289,000 in women ${ }^{1}$ and 2,900,000 in newborns ${ }^{2}$ in 2013. Furthermore, breast milk is a complete food for the infant during the first 6 months of life ${ }^{3}$, which also reduces the woman's risk of suffering diabetes mellitus, breast cancer, and ovarian cancer $^{3}$. According to national reports, $12.7 \%$ of children of Mexican adolescents born between 2009 and 2014 received exclusive breastfeeding, with an average of 6.9 months of breastfeeding 4 .

According to several studies in Latin America, the practices carried out during the puerperium are guided not only by biomedical knowledge but also by the women's family ${ }^{5-7}$. It is also believed that the women carelessness results in the experience of abdominal cramps, low back and bone pain, and fever, even after a year of childbirth ${ }^{8}$.

For example, in the case of Colombian and Chilean adolescents, avoiding exposure to sun, rain, and the "sereno," maintaining hygiene, decreasing sexual and physical activity and consuming broths or soft foods are key elements during the puerperium ${ }^{6}$.

In studies with Mexican ${ }^{10,11}$ and Colombian ${ }^{12}$ adolescents, some factors that hinder breastfeeding, such as the perception of insufficient breast milk production ${ }^{10-12}$, leisure ${ }^{12}$ and work, domestic activities ${ }^{10,11}$, fear of transmitting diseases to the newborn ${ }^{10-12}$, and over-attention of males in public places when the woman breastfeeds, experiencing flat nipple, mastitis, or cracked nipples ${ }^{12}$ were identified. Regarding extended breastfeeding after 6 months, it was identified that women perceive a social judgment on the part of their families since it is considered that the breasts are an erogenous zone and that they should only get in touch with the infant when he is a newborn ${ }^{10}$. Facilitating factors such as being a housewife and perceiving enough milk production were identified $^{12}$. Besides, according to Pérez and Moreno ${ }^{13}$, breastfeeding is conceived as an inherent biological instinct of being a good mother and woman, yet breastfeeding is rather an idealized experience where no barriers of any kind are conceived. Studies with Colombian ${ }^{8,12}$, Honduran $^{14}$, and Mexican ${ }^{15}$ adults have reported that, although they recognize the value of breast milk, they combine biomedical and cultural knowledge in their practice; for example, they ignore whether breast milk should or should not be given to infants with diarrhea ${ }^{15}$ and consume herbal medicine to improve lactogenesis ${ }^{14}$.

Regarding newborn care, studies conducted in Colombia ${ }^{12,16}$ indicated that adolescent mothers understand their care as practices related to the maintenance of hygienic environments, preservation of body temperature and incorporation of plain water and fruits into the baby's diet before 6 months, when breast milk cannot be given. Studies in adult women in Brazil ${ }^{17}, \mathrm{Chile}^{18}$, Colombia ${ }^{7,8,14}$, and Portugal ${ }^{19}$ report that the newborn care is characteristically stressful due to the lack of knowledge about the newborn reactions ${ }^{18}$, where the mother's learning is mainly empirical, having little or no orientation by health personnel ${ }^{17}$; as a result, it becomes a part of exclusive women practices and is only guided by them ${ }^{14,17,19}$. Among the subtopics identified, the following elements were reported: the hygiene of the feeding utensils ${ }^{7}$, avoiding the exposure of the newborn to sun, abdominal compression bandage ${ }^{8}$ and alcohol application ${ }^{7}$ for the umbilical cord, the use of amulets to avoid diseases ${ }^{7,8}$, isolation at home for 3 months $^{7}$, and the use of herbal medicines during the bath to facilitate rest and preserve the temperature ${ }^{8}$.

The studies cited above reveal that there are multiple practices of women during the puerperium, lactation, and neonatal care, all different according to the geographical context and the age of the women. Furthermore, these practices are guided mostly by female relatives and not by qualified health personnel. In this sense, it is important to know and identify the mechanisms 
through which these practices are perpetuated, especially in the adolescent population, on account of the $8 \%$ decrease in exclusive breastfeeding during the period from 1999 to $2012^{20}$, as well as the high risk of low-birth-weight and other health problems related to poverty and the lack of access to health services ${ }^{21}$.

This study presents results about the knowledge, beliefs, and attitudes of adolescent mothers toward puerperium, lactation, and newborn postnatal care, which are derived from the secondary analysis of data collected in a previous investigation with mixed methodology on maternal representations of primigravid adolescents $^{22}$. The qualitative data were recollected and analyzed through the theory of social representations of Moscovici23 because this theoretical framework allows analyzing the transmission of lay knowledge about daily life phenomena among individuals of a society. According to Moscovici23, representations are individual modes of thinking through which reality is re-represented analogically as a play, where each group or social group resignifies reality according to their individual experiences and their historical background.

\section{Methods}

\section{Study design}

An interpretative study ${ }^{24-26}$ was carried out based on the theory of social representations ${ }^{23}$. The data collection was retrolective ${ }^{27}$, with the objective of knowing the emic perspective of the primigravid adolescents about the puerperium, lactation, and care of the newborn.

\section{Participants}

We studied 30 adolescents who attended prenatal care in the Gynecology and Obstetrics Service of the Hospital Unit Fray Antonio Alcalde of the Hospital Civil of Guadalajara, in Guadalajara, Jalisco, Mexico, during 2015.

In the present study, a purposive sampling ${ }^{28}$ was carried out using the snowball technique to contact the participants. Eligibility criteria were to be between 10 and 19 years old and to be primigravida. The criteria for non-eligibility were residing outside the metropolitan Guadalajara area and the refusal to the interview recording.

\section{Procedures and data analysis}

The administrative staff of the medical unit allowed the researchers to enter the gynecology and obstetrics area, where they contacted the adolescents. The interested patients were summoned subsequently to be interviewed in a cubicle that the institution provided; in addition, when the patients were minors, the tutors or their partners were invited as witnesses of the processes. The sessions' duration was from 24 to 46 min; no participant was excluded by the length of the session because there was no limit of time to evaluate the quality of an interview ${ }^{28}$. However, the following criteria were taken into account: obtaining the informed consent, choosing a private place without distractors for the interview, the use of colloquial language by the interviewers and showing an empathic and curious attitude to what was mentioned by the participants ${ }^{28}$.

A Spanish translation of the Interview of Maternal Representations during pregnancy ${ }^{29}$ was applied, with which the social representation of maternity in pregnant adolescents of the metropolitan area of Guadalajara, Jalisco, was explored. This instrument examines the following aspects: the desire for pregnancy, emotions during pregnancy, lifestyle changes, perceptions, and fantasies toward the infant, expectations toward the mother's lifestyle, and the influence of personal history in the maternal representations.

For this work, the data collected were analyzed based on the following questions: what are the knowledge, beliefs, attitudes, and practices of the primigravid adolescents regarding puerperium, lactation and newborn care? Moreover, what are the social meanings that justify adolescents' ways of thinking and acting on the study topics?

The previous questions were constructed from the principles of the theory of social representations. First, according to which the social representations constitute ways of thinking (attitudes, emotions, and beliefs), where the phenomena are endowed with meaning and symbolism produced individually and collectively. Second, they support the formation of personal identities, as well as they guide and justify the individual and collective practices and attitudes toward the world in its context $^{23}$.

Classical content analysis ${ }^{30}$ and Atlas.ti software were used for data processing. This processing consisted of the coding and decomposition of the transcribed interviews in units of text labeled according to the observed meaning. The meaning was identified by observing the use of nouns, verbs, adverbs, and adjectives as keywords. Furthermore, the categorization, classification, and hierarchization of the text units by related themes and inference were performed, which included identifying the existing relationships between the 
categories and how they respond to the research question. For this process, the guiding questions were considered the starting points. As a result of the analysis phase, it was produced a conceptual map in which the representations were described. The descriptive statistical analysis was also carried out, where frequencies and percentages of each text unit appearance were obtained showing the predominance of some units over others.

Regarding the ethical and legal aspects, the previous investigation was approved in its protocol phase by the Research Ethics Committee of the Hospital Civil of Guadalajara, Fray Antonio Alcalde Hospital Unit, which granted the registration number 03-15. Moreover, in the case of minors, informed consent was obtained from the tutors and anonymity was ensured according to the "Ley federal de protección de datos personales en posesión de los particulares" (Federal Law on Protection of Personal Data Held by Individuals) ${ }^{31}$.

\section{Results}

The participant's average age was 16.8 years (13-19 years). $36.7 \%(n=11)$ were single, $16.7 \%(n=5)$ married, and $46.7 \%(n=14)$ lived in free union. The mean number of weeks of pregnancy at the time of the study was 33.1 (range of 24-41 weeks).

Concerning the adolescent's sociocultural context, a minority mentioned that they were studying. The rest had planned to join the high school or a technical career.

The assistance of the patients to a public hospital indicated their low-income level. Furthermore, the relationship with their family was characterized by conflicts derived from the economic costs produced by the newborn's birth and the transcendence of the newborn as a new beginning or congratulation. In the idiosyncrasy of the relatives, the mothers, and their partners, and the newborn must be exempted from all responsibility for the acts of adults and represents for parents a mean of vindication of the early pregnancy.

Through the content analysis, 22 codes were identified concerning three representations: "mother and child must be synchronized", "breastfeeding: practice converted into a myth," and "newborns are fragile" (Table 1).

Figure 1 shows the conceptual map that describes the relationships between codes and representations. This map is read from left to right and from top to bottom and shows three elements: the social representations, the elements that foster and maintain the social representations, and the codes identified during the analysis. Below, each representation is explained and illustrated with portions of the interviews.

\section{Mother and child must be synchronized}

The woman's recovery during the puerperium was related to practices that made resting possible. In this sense, achieving synchronization between the mother's sleep schedules and the feeding and napping of the newborn represented an important goal; one mother commented: "To get the child accustomed to certain sleeping and eating rhythms, to make the child have my sleeping rhythm rather."

\section{Breastfeeding: practice converted into a myth}

The adolescents showed little knowledge and reported that they expected to be guided by their female relatives. One mentioned: "I hope to breastfeed. My mom would explain to me what I need". Furthermore, they perceived that breastfeeding is a practice hindered by study or work activities. Another said: "As I am going to continue studying, I will not be able to be there to give milk to the baby, I mean breastfeed, and I will have to give him a bottle." In addition, although several adolescents demonstrated positive emotions toward breastfeeding, most said that the milk formula was an adequate complement or substitute. Some pointed out: "If you do not produce much milk, it is good to supplement it with a bottle"; "I will give breast milk and formula as well, I have seen that if you only give them breastfeeding, they do not grow well."

\section{Newborns are fragile}

The care of the children was seen as an exclusive woman practice in which they assumed control despite the need to join work or academic activities. Some expressed: "It is going to be very fragile, I will be the one who even checks if the baby breathes and everything else," "I do not want to be one of those mothers who leave their children so that they can go to work. I would like to be with him and take care of him." The care included maintaining clean environments, feeding the newborn and achieving its adaptation to the environment. One participant mentioned: "He should not get bothered with noise, instead to get used to it, to the 
Table 1. Representations and codes identified in the interviews

Representations/codes

Breastfeeding: practice converted into a myth

They will combine breast milk and milk formula

Negative emotions

Female relatives help and advise

Adolescents will give milk formula

Breast milk gives energy to the baby

Positive emotions

Not every woman produces good quality milk

Work and school impede breastfeeding

Adolescents will give exclusive breastfeeding

Breastfeeding makes the breast flaccid

Health staff advises adolescent

Babies do not always tolerate breast milk

Breastfeeding contributes to weight loss

Newborns are fragile

Babies require women's care

The relatives and partner provide material resources

Babies require clean environments

Babies require food

Babies need to be loved and to adapt to the environment

The adolescent will take care of the baby indefinitely

Other women contribute to the care of the baby

Mother and child must be synchronized

Female relatives help and give advice

Babies should adapt to the mother sleep rhythms
Frequency (\%)

77 (40.5)

20 (10.5)

$15(7.9)$

8 (4.2)

8 (4.2)

8 (4.2)

4 (2.1)

$4(2.1)$

$4(2.1)$

$2(1.1)$

1 (0.5)

$1(0.5)$

1 (0.5)

$1(0.5)$

95 (50.0)

8 (4.2)

$3(1.6)$

$15(7.9)$

22 (11.6)

$17(8.9)$

19 (10.0)

$11(5.8)$

$18(9.5)$

8 (4.2)

$10(5.3)$ light and other things of that kind"; "I think I will be overprotective so that everything would be clean."

\section{Discussion}

The results described above reaffirm that the adolescent's experience concerning puerperium, breastfeeding, and newborn care are ambivalent. They live positive emotions, but the reincorporation to their routine activities makes it difficult to carry out desirable actions such as breastfeeding. In the same way, a latent need to incorporate the newborn into their daily life is expressed. For example, they desire that the baby gets used to noise, light, and the mother's sleep rhythm, but there is also concern and anxiety about separation from the newborn.

As in other contexts ${ }^{9-12,16,17}$, the participants of this study experience family tensions due to their early motherhood; in this sense, they coincide in the fact that they are guided and supported mostly by other women in their family. The incorporation to work or school was an obstacle for breastfeeding as in other studies ${ }^{10-12}$. Probably, these coincidences are a result of the fact that women visualize motherhood as an instinct, which encourages them to be more perceptive to the information derived from other women experiences, and not to the information provided by the health personnel, perpetuating in this way the beliefs and practices that 


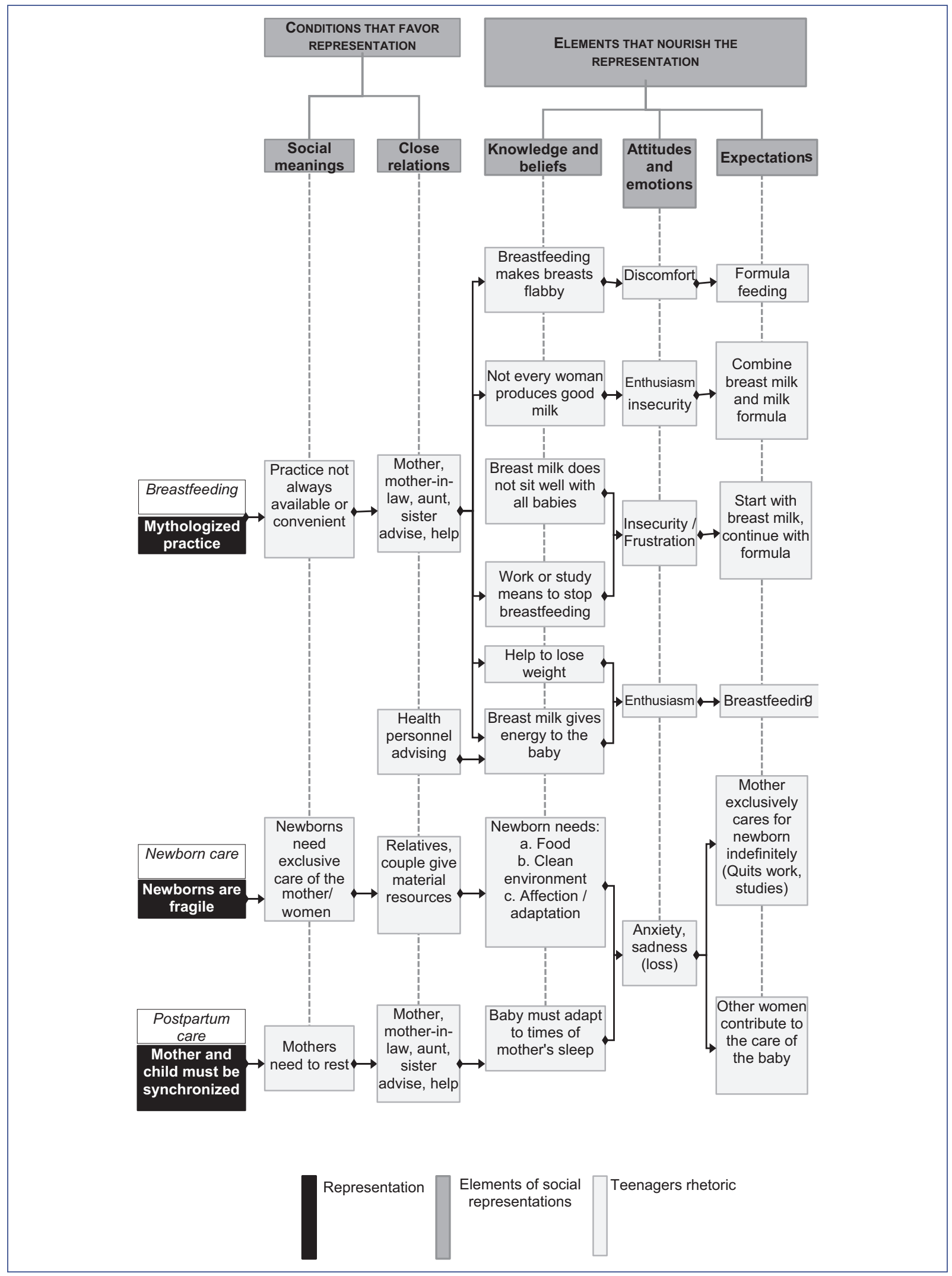

Figure 1. Conditions and elements of social representations of the primigravid Mexican adolescents on breastfeeding, also newborn, and puerperium care.

The sum of the categories represents $100 \%$ (text in italics). The sum of the codes (normal text) represents the total of the category to which they belong. 
disagree with current scientific knowledge and exposing them to risks. However, in this work, it was identified that adolescents have a positive perception of milk formulas as a complement or substitute for breast milk, unlike what is reported in other studies $8,12,14,15$, an aspect that may be due to the absence of advice from qualified health personnel.

It was also shown that the neonate care is a women's activity, as described by other authors ${ }^{14,17,19}$. In the same way, the maintenance of clean environments was fundamental, similar to the reported in other studies ${ }^{12,14}$. It should be noted that the adolescents in the current study expressed higher expectations of combining their activities with their children's needs of food and rest, although the care during the puerperium does not appear as a reason for concern or doubt in adolescents. This could indicate changes in the knowledge and beliefs about the puerperium of women in that context. For example, the perception that the needs of women during the puerperium are in a second level compared with those of the child-an aspect that coincides with the idea that a "good" mother sacrifices her needs by putting the ones of the child first ${ }^{13}$.

Moreover, the partner partial or total absence produced the need for the participants to develop self-sufficiency; also, this absence emphasized the negative emotional charge (worry and frustration). In the same way, the women's intention of preserving the breasts esthetics could be due to the expectation of continuing to be perceived as young to project this image toward society and increase the possibility of finding another partner.

Concerning the novel knowledge of the current study, two elements were identified. First, at the individual level, the adolescents experience enthusiasm for feeding their child with breast milk, but also anxiety and frustration when visualizing obstacles that can hinder that process, which can be an opportunity area to develop health education programs focused on training primigravidas to overcome the difficulties related to breastfeeding and newborn care, as well as raising awareness and education about the necessity of care during the puerperium. Second, at a social level, it is important to note that adolescents refer to their female relatives as their closest support networks; therefore, this should be considered within the educational interventions of health institutions.

Regarding the scope of the study, the authors consider that the use of qualitative methods facilitated the understanding of the content and the structure of what was reported by the participants. However, the hospital environment was a limitation, given that some adolescents were uncomfortable with it, which made it difficult in some instances to obtain more extensive interviews. Furthermore, the male perspective on the subject is unknown, which constitutes an opportunity gap for future research.

The reported findings represent an update on the perceptions, attitudes, and knowledge of Mexican adolescents about puerperium, breastfeeding, and newborn care.

\section{Ethical disclosures}

Protection of human and animal subjects. The authors declare that no experiments were performed on humans or animals for this study.

Confidentiality of data. The authors declare that no patient data appear in this article.

Right to privacy and informed consent. The authors declare that no patient data appear in this article.

\section{Conflicts of interest}

The authors declare no conflicts of interest.

\section{Acknowledgments}

The authors thank the study participants for sharing their experiences, as well as to the anonymous reviewers assigned to this manuscript, for their valuable contributions to improving its quality.

\section{References}

1. World Health Organization. Trends in maternal mortality: 1990-2013, Estimates by WHO, UNICEF, UNFPA, The World Bank and the United Nations Population Division. [Internet]. Geneva: World Health Organization; 2013. Available at: http://bit.ly/1vwzpN7.

2. Lawn JE, Blencowe H, Oza S, You D, Lee AC, Waiswa P, et al. Every newborn: progress, priorities, and potential beyond survival. Lancet. 2014;384:189-205. Available at: http://bit.ly/2kTNbsO.

3. World Health Organization. Breastfeeding. [Internet]. Geneva.: World Health Organization; 2007. Available at: http://bit.ly/1g2Fzlo.

4. Instituto Nacional de Estadística y Geografía. Encuesta Nacional de la Dinámica Demográfica 2014. [Internet]. Mexico: Instituto Nacional de Estadística y Geografía; 2015. Available at: http://bit.ly/2maoZ87

5. Laza-Vázquez C, Puerto-Lozano Ml. Cuidados genéricos para restablecer el equilibrio durante el puerperio. Rev Cubana Enfermer. 2011;27:8897. Available at: http://bit.ly/2mgSZdK.

6. Behar R. Trastornos de la conducta alimentaria, embarazo y puerperio. Méd UIS. 2013;26:21-8. Available at: http://bit.ly/2hNsnka.

7. Del Toro M, Fernández S, González G, Díaz A. Aspectos culturales de la puérpera que influyen en el cuidado del primer hijo. Rev Cubana Enfermer. 2016;32:37-48. Available at: http://bit.ly/2iKDTOh.

8. Prieto BM, Ruiz $\mathrm{CH}$. Significados durante el puerperio: a partir de prácticas y creencias culturales. Aquichan. 2013;13:7-16. Available at: http:// bit.ly/2B6qqHm.

9. Cardozo-Silvia SL, Bernal-Roldán MC. Adolescentes en puerperio y sus prácticas de cuidado. Av Enferm. 2009;27:82-91. Available at: http://bit. ly/2lglg5x. 
10. Quezada-Salazar CA, Delgado-Becerra A, Arroyo-Cabrales LM, Díaz-García MA. Prevalencia de lactancia y factores sociodemográficos asociados en madres adolescentes. Bol Med Hosp Infant Mex. 2008;65:19-25. Available at: http://bit.ly/2ks4Rx8.

11. Sena-Barrios A, Rivera-Rivadulla R, Díaz-Guzmán E, Hernández-Domínguez B, Armas-Ramos N. Caracterización de la lactancia materna en madres adolescentes. Rev Ciencias Méd Pinar del Río. 2014;18:574-89. Available at: http://bit.ly/2la093Z

12. Forero $Y$, Rodríguez M, Isaács MA, Hernández JA. La lactancia materna desde la perspectiva de madres adolescentes de Bogotá. Biomédica. 2013;33:554-63. Available at: http://bit.ly/2ilTOrw.

13. Pérez MD, Moreno A. Dando voz a las mujeres: representaciones sociales y experiencias sobre la lactancia. Dossiers Feministes. 2017;22:10717. Available at: http://bit.ly/2mXiAxk.

14. Gale SC, Erazo K. Lactancia materna exclusiva: expectativa versus realidad. Act Ped Hond. 2015;5:355-60. Available at: http://bit.ly/2A1Uk20.

15. Cortés-López MC, Torres-López TM, Larrosa-Haro A, Covarrubias-Bermúdez MA. Prácticas de alimentación y rehidratación realizadas por madres mexicanas de lactantes diagnosticados con diarrea. Arch Med. 2017;13:1-10. Available at: http://bit.ly/2zx1HQ1

16. Argote LA, Vázquez ML. La "dieta" como camino para asegurar un hijo sano: una mirada desde el mundo urbano de las adolescentes. Colomb Med. 2005;36:58-64. Available at: http://bit.ly/2mgHyCF.

17. Turiani M, Pamplona-Tonete VL, Komura L, Chávez-Alvárez RE. El cuidado del niño: representaciones y experiencias de la madre adolescente de bajos recursos. Index Enferm. 2009;18:90-4. Available at: http://bit.ly/2/p2rfV.

18. Lucchini C, Márquez F, Rivera M. "Yo quiero amamantar a mi hijo": Develando la experiencia de mujeres que enfrentaron dificultades en su proceso de lactancia. Rev Chil Pediatr. 2017;88:591-7. Available at: http://bit.ly/2hMbab5.

19. Frade J, Pinto C, Carneiro M. Ser padre y ser madre en la actualidad: repensar los cuidados de enfermería en el puerperio. Matronas Prof. [Internet]. 2013;14:45-51. Available at: http://bit.ly/2krwDts.
20. Gutiérrez JP, Rivera-Dommarco J, Shamah-Levy T, Villalpando-Hernández S, Franco A, Cuevas-Nasu L, Romero-Martínez M, et al. Encuesta Nacional de Salud y Nutrición 2012. Resultados Nacionales. [Internet]. Cuernavaca: Instituto Nacional de Salud Pública; 2013. Available at: http://bit.ly/lvnQ2d.

21. World Health Organization. Adolescent pregnancy. [Internet]. Geneva: World Health Organization; 2014. Available at: http://bit.ly/1EDJsP5.

22. Franco-Ramírez JA. Representaciones maternas en las adolescentes embarazadas primigestas. [Thesis]. León, Mexico: Círculo de Estudios de Psicología Profunda; 2016.

23. Moscovici S. El psicoanálisis, su imagen y su público. Buenos Aires: Huemul; 1979.

24. Lincoln YS, Guba EG. Paradigmatic Controversies, Contradictions, and Emerging Confluences. In: Denzin NK, Lincoln YS, editors. Handbook of qualitative research. Thousand Oaks: SAGE Publications; 1994. pp. 163-8.

25. Heron J, Reason P. A participatory inquiry paradigm. Qualitative Inquiry. [Internet]. 1997;3:274-94. Available at: http://bit.ly/2IQW84A.

26. Hjørland B. Empiricism, rationalism and positivism in library and information science. J Doc. 2005;51:130-55. Available at: http://bit.ly/2ArpJfx.

27. Feinstein AR. Clinical Biostatistics. Saint Louis: Mosby; 1977.

28. Ritchie J, Lewis J, Nicholls C, Ormston R, editors. Qualitative research practice: A guide for social science students and researchers. Thousand Oaks: SAGE Publications; 2013.

29. Ammaniti M, Tambelli R. Prenatal Self-Report Questionnaires, Scales and Interviews. In: Tyano S, Kerem M, Herrman H, Cox J. Parenthood and mental health. A bridge between infant and adult psychiatry. London: Wiley-Blackwell; 2010. pp. 109-20.

30. Bardin L. Análisis de contenido. Barcelona: Akal; 1996

31. Ley federal de protección de datos personales en posesión de los particulares. [Internet]. Mexico D.F.: Diario Oficial de la Federación de los Estados Unidos Mexicanos; 2010. Available at: http://bit.ly/ 1 vauawz. 